\title{
Piores Formas de Trabalho Infantil / Worst Forms of Child Labor
}

https://doi.org/10.21814/uminho.ed.36.49

Isabel Jijón

Princeton University, United States of America 



\section{Piores Formas de Trabalho Infantil}

O trabalho infantil refere-se a uma diversidade de práticas económicas, mas, nas últimas décadas, investigadores, ativistas e líderes de organizações do trabalho e dos direitos das crianças, têm especificado que um subconjunto destas práticas são "as piores formas de trabalho infantil". As piores formas incluem escravidão, a venda de crianças traficadas, crianças em trabalhos forçados, crianças em servidão por dívida, crianças soldado, prostituição infantil, pornografia infantil, crianças na produção e tráfico de droga, e, em geral, "os trabalhos que, pela sua natureza ou pelas condições em que são exercidos, são susceptíveis de prejudicar a saúde, a segurança ou moralidade das crianças" (Convenção n. ${ }^{\circ}$ 182, Artigo 3. ${ }^{\circ}$ ).

A Organização Internacional do Trabalho (OIT) codificou as piores formas de trabalho infantil na sua Convenção n. ${ }^{\circ} 182$ (C182). Este documento impele os Estados, as organizações da sociedade civil e o público em geral, a fazer da erradicação das piores formas de trabalho infantil a sua máxima prioridade. Os Estados comprometem-se a evitar que as crianças entrem nestas atividades, a retirar as crianças que já estão nestas atividades, a providenciar alternativas seguras para as crianças vulneráveis e a proteger as crianças em risco, especialmente as meninas (Artigo 7. ${ }^{\circ}$ ). A Convenção, por outras palavras, pressiona os agentes a "tomar medidas imediatas e efetivas "e a tratar as piores formas de trabalho infantil "como um assunto urgente" (Artigo 1..$^{\circ}$.

A Convenção n. ${ }^{\circ} 182$ da OIT foi adotada em 17 de junho de 1999. Foi um sucesso imediato, "a Convenção mais rápida e amplamente ratificada da história da OIT" (Cullen, 2005, p. 94). A C182 constitui uma rutura em relação às anteriores políticas internacionais relativas ao trabalho infantil, particularmente a Convenção n. ${ }^{\circ} 138$ da OIT sobre a Idade Mínima de admissão ao emprego. Antes de 1990, a OIT tinha adotado uma visão "abolicionista" em relação ao trabalho infantil. Isto significa que a organização entendeu o trabalho infantil em termos de um binómio moral e legal: o trabalho leve é bom e deveria ser permitido; o trabalho infantil é imoral e deveria ser proibido; o trabalho infantil deveria ser proibido. A Convenção n. ${ }^{\circ} 182$ sobre as Piores Formas de Trabalho Infantil, pelo contrário, expõe uma abordagem de "priorização" ou de "primeiras coisas primeiro". Isto significa que a OIT 
reconhece agora que o trabalho infantil encobre muitas atividades diferentes e propõe que os agentes combatam primeiro as atividades mais perigosas e prejudiciais (97).

Académicos e representantes de organizações não-governamentais (ONG) dedicadas aos direitos das crianças foram ativamente envolvidas no esboço da Convenção da OIT sobre as Piores Formas de Trabalho Infantil. É por isso que este documento utiliza pesquisa mais explícita sobre o trabalho infantil. A C182 reconhece as causas e as consequências do trabalho infantil assim como o impacto dos diferentes tipos de intervenção. Ela especifica a necessidade de práticas alternativas (White, 2005).

Em abril de 2020, 186 países e territórios ratificaram esta Convenção, tornando-a um dos mais bem sucedidos tratados da OIT. Esta Convenção tem mais ratificações do que os dois outros tratados internacionais anteriores, respeitantes ao trabalho infantil: a Convenção de 1973 da OIT sobre a Idade Mínima para admissão ao emprego e a Convenção das Nações Unidas sobre os Direitos da Criança, em 1989.

Em 2016 (a estimativa global mais recente) havia 152 milhões de crianças a trabalhar nalguma forma de trabalho infantil. Cerca de metade - 73 milhões de crianças - trabalhavam nas piores formas de trabalho infantil (OIT 2017, p.23). Isto é, 100 milhões de crianças menos do que em 2000 (171 milhões) (23), contudo a OIT tinha previsto que o mundo iria eliminar as piores formas em 2016. 0 objetivo, por outras palavras, não foi alcançado (24). 1 em cada 20 crianças, encontra-se, hoje, nas piores formas de trabalho infantil (28).

Enquanto a Sociologia da Infância se centra nas crianças, na abordagem que faz do trabalho infantil, estudando a experiência do trabalho infantil do ponto de vista das próprias crianças trabalhadoras, os académicos ainda não examinaram a experiência das crianças nas piores formas de trabalho infantil. Sabemos pouco acerca daquilo que as crianças vivenciam, que sentido tem para elas essas práticas e que alternativas elas teriam ou escolheriam.

A pesquisa futura deveria expandir o centrar-se na criança, e estar atenta, claro, às dificuldades éticas e práticas de estudar crianças marginalizadas (Corsaro, 2005, pp. 56-58). Os académicos deveriam também desenvolver mais trabalhos comparativos, encontrando as diferenças e semelhanças entre os diferentes tipos de atividades perigosas. 


\section{Worst Forms of Child Labor}

Child labor refers to a variety of economic practices but, in the past few decades, scholars, activists, and the leaders of child rights and labor organizations have specified that a subset of these practices is the "worst forms of child labor". The worst forms include child slavery, the sale and trafficking of children, children in forced labor, children in debt bondage, children in armed forces, child prostitution, child pornography, children in drug production and drug trafficking, and, in general, "work which, by its nature or the circumstances in which it is carried out, is likely to harm the health, safety or morals of children" (C182, Article 3).

The International Labor Organization (ILO) has codified the worst forms of child labor in its Convention No. 182 (C182). This document pushes states, civil society organizations, and the public at large to make the eradication of the worst forms of child labor their top priority. States are now committed to preventing children from entering these activities, to removing children who are already engaged in these activities, to providing safer alternatives for vulnerable children, and to protecting children who are at risk, especially girls (Article 7). The convention, in other words, pushes actors to "take immediate and effective measures" and to treat the worst forms of child labor "as a matter of urgency" (Article 1).

The ILO's Convention No. 182 was adopted on June 17, 1999. It was an immediate success, "the most rapidly and widely ratified convention in ILO history" (Cullen, 2005, p. 94). This convention represented a break from previous international policies towards child labor, most notably the ILO's Convention No.138 on the Minimum Age for Employment. Prior to 1999, the ILO had adopted an "abolitionist" view towards child labor. This meant that the organization understood child labor in terms of a moral and legal binary: light work is good and should be allowed; child labor is immoral and should be prohibited; child labor should be prohibited using blanket bans. The Convention No. 182 on the Worst Forms of Child Labor, in contrast, follows a "prioritization" or "first things first" approach. This means that the ILO now recognizes that child labor covers many different activities and instead proposes that actors fight the most dangerous and harmful activities first (97).

Academics and representatives from non-governmental organizations (NGOs) dedicated to children's rights were actively involved in the drafting of the ILO's Convention on the Worst Forms of Child Labor. That is why this document draws more explicitly on child labor research. C182 acknowledges the 
causes and consequences of child labor, as well as the impact of different types of interventions. It specifies the need for practical alternatives (White, 2005).

As of April 2020, 186 countries and territories have ratified this convention, making it one of the ILO's most successful treaties. This Convention has more ratifications than the two other international treaties concerning child labor: the ILO's 1973 Convention on the Minimum Age for Employment and the UN's 1989 Convention on the Rights of the Child.

By 2016 (the most recent global estimates), there were 152 million children employed in some form of child labor. Almost half - 73 million children were in the worst forms of child labor (ILO 2017: 23). This is 100 million fewer children than those in the worst forms in 2000 (171 million children) (23). However, the ILO had predicted that the world would eliminate the worst forms by 2016. The goal, in other words, has not been met (24). 1 in 20 children are still in the worst forms of child labor today (28).

While the sociology of childhood has taken a "child-centric turn" in its approach to child labor, studying the experience of child labor from the viewpoint of working children themselves, scholars have still not examined the experience of children in the worst forms of child labor. We know little about what children go through, how they make sense of their practices, and what alternatives they have or would choose.

Future research, therefore, should expand the child-centric turn, being mindful, of course, of the practical and ethical difficulties of studying marginalized children (Corsaro, 2005, pp. 56-58). Scholars should also conduct more comparative work, finding the similarities and differences behind the different types of dangerous occupations.

\section{Referências / References}

Corsaro, W. (2005). The sociology of childhood. London: Sage.

Cullen, H. (2005). Child labor standards: From treaties to labels. In B. H. Weston (Ed.), Child labor and human rights: Making children matter (pp. 87-115). Boulder, CO: Lynne Rienner Publishers.

International Labour Organization (2017). Global estimates of child labour: Results and trends, 2012-2016. Geneva: International Labour Office.

White, B. (2005). Shifting positions on child labor: The views and practice of intergovernmental organizations. In B. H. Weston (Ed.), Child labor and human rights: Making children matter (pp. 319 -342). Boulder, CO: Lynne Rienner Publishers. 